\title{
MEMBANGUN LINGKUNGAN INTERNET SEHAT DI RUMAH TINGGAL DENGAN MENGGUNAKAN APLIKASI WEB FILTERING
}

\author{
Erika Ramadhani ${ }^{1}$, Afif Wika Sadewa ${ }^{2}$ \\ Jurusan Teknik Informatika, Fakultas Teknologi Industri, Universitas Islam Indonesia, ${ }^{1,2)}$ \\ Jl. Kaliurang Km. 14,5 Sleman, Yogyakarta 55584 \\ E-Mail : erika@uii.ac.id ${ }^{1}$,afifwisadewa@gmail.com²
}

\begin{abstract}
Healthy internet is a human activity that access to the public network that the Internet is done in an orderly manner, good, and ethical in accordance with norms and rules that apply in the community. Healthy internet usage is also by not doing unlawful internet activity, one of them is accessing illegal content (adult website). Currently, the use of Internet technology in the home environment has been very developed, with the ease that given the use of the Internet will be increasing. The problem is how to create a healthy internet environment by not accessing adult website links so that it can be protected from the access of children under age in the neighborhood. To maintain the activities of Internet use at home, then made an application that serves to monitoring the access to the Internet, especially to block the activities of accessing illegal content. This application is made by implementing Squid by way of doing filtering to access web. The results of this study is an application that can be used to monitor the Internet access at home. So it can create a healthy internet environment at home.
\end{abstract}

Keywords : Healthy Internet, Web Filtering, Squid, Keywords, Blocking, Monitoring, Internet.

\section{PENDAHULUAN}

Saat ini segala sesuatu dapat diakses secara digital melalui Internet bahkan semakin mudahnya mengakses Internet dapat dilakukan oleh siapa saja dan dimana saja baik itu kalangan pelajar, mahasiswa ataupun pekerja. Dalam mengakses Internet dapat diakses melalui media berupa gadget, laptop ataupun komputer. Selain memiliki dampak positif, Internet juga mempunyai dampak negatif, contohnya adalah semua orang memiliki akses yang mudah untuk melihat atau browsing content negative semisal pornografi. Oleh karena itu perlu diadakan sistem pengawasan untuk mengawasi segala pola perilaku menyimpang tersebut.

Ada program pemerintah demi mendukung Internet sehat yaitu suatu program dari Indonesia yang dicanangkan oleh Kementerian Komunikasi dan Informatika Indonesia (Kemkominfo) dengan tujuan untuk mensosialisasikan penggunaan Internet secara sehat dan aman melalui pembelajaran etika ber-Internet secara sehat dengan melibatkan seluruh komponen masyarakat. Menurut Kemkominfo jumlah pengguna Internet di Indonesia mencapai 82 juta orang dan berada pada peringkat ke-8 dunia, dari jumlah tersebut, 80 persen di antaranya adalah remaja berusia 15-19 tahun, untuk pengguna Facebook, Indonesia berada diperingkat 4 dunia, dengan jumlah pengguna Internet yang mayoritas menggunakan jejaring sosial dan berbagai akses informasi maka sangat diperlukan edukasi yang tepat mengenai Internet itu sendiri (Kemkominfo, 2013).

Pengaruh konten negatif di Internet berupa pornografi, perjudian, penipuan, pelecehan, pencemaran nama baik, cyberbullying, dan kejahatan dunia maya menjadi alasan mengapa diperlukannya sosialisai dan pengenalan mengenai bagaimana perlunya memperkenalkan penggunaan Internet yang baik dan sesuai. Sehingga dapat mengatasi bahaya yang mengancam dari dan konten - konten negatif yang ada, Kemkominfo sendiri berusaha 
mengubah citra Internet menjadi sepenuhnya positif (Kemkominfo, 2013).

Bukan hanya Internet sehat saja yang harus di perhatikan dalam menuju perilaku positif dalam mengakses Internet diperlukan juga sistem keamanan dalam pengaksesan di Internet. Sebagai contoh adalah seorang pengguna apabila memiliki akses Internet dapat dengan bebas mengakses segala macam informasi tanpa ada batasan-batasan yang menjaga agar perilaku buruk seperti membuka situs - situs yang mengandung unsur pornografi dan tindak asusila serta yang mengandung kekerasan dapat dengan mudah diakses oleh siapapun dan dimanapun asalkan memiliki akses Internet dan juga mempunyai smartphone ataupun gadget. Terlebih lagi apabila anak-anak yang dibawah umur mengakses hal-hal yang berunsur negatif maka akan berdampak pada sifat dan perilaku anak tersebut baik itu secara langsung maupun tidak langsung.

Teknologi Internet sudah menjadi bagian hidup dari setiap orang. Hampir setiap hari dan hampir setiap waktu kebutuhan akan Internet tidak terpisahkan. Sehingga instalasi Internet tidak saja di lakukan di kantor atau ditempat kerja, instalasi Internet juga sudah menjadi kewajiban untuk dipasang di rumah tinggal. Permasalahannya adalah bagimana caranya agar pengaksesan Internet bisa termonitoring dengan benar untuk menghindari anak dibawah umur mengakses konten ilegal dirumah.

Demi memberikan batasan-batasan dalam pengaksesan Internet maka dibangunlah sebuah lingkungan internet sehat dirumah dengan menggunakan aplikasi web filtering dengan menggunakan squid. Aplikasi ini merupakan aplikasi yang digunakan untuk mebatasi alamat website ataupun keyword yang digunakan dalam pengaksesan Internet. Aplikasi ini terhubung dengan Squid yang berada pada komputer server, aplikasi ini berbasiskan web, sehingga dapat mempermudah admin dalam membatasi pengaksesan Internet oleh pengguna. Hasil dari penelitian ini adalah berupa aplikasi yang bisa dimanfaatkan untuk melakukan monitoring terhadap akses Internet dirumah. Sehingga bisa menciptakan lingkungan internet sehat dirumah.

\section{STUDI LITERATUR}

\subsection{Internet Sehat}

Pengertian dari Internet sehat sebenarnya banyak sekali definisinya tetapi secara garis besar adalah, segala aktivitas pengguna Internet saat browsing, chatting, upload, download secara tertib sesuai peraturan yang berlaku baik itu di masyarakat biasa ataupun dikalangan tertentu yang tidak melakukan sesuatu yang melanggar hukum dan merugikan pengguna Internet lain contohnya seperti hak cipta (ilegal), hacking dan mengakses konten ilegal (situs dewasa), serta bullying (mengolok olok pengguna lain) di Internet (T. Agustina, 2013).

Pengertian dari Internet sehat bukan berarti Internet itu dapat sakit, Internet bukanlah manusia yang harus di obati ketika sakit, arti dari Internet sehat disini adalah karena Internet di jaman sekarang ini menjadi hal yang dapat dibilang sudah menjadi prioritas dikalangan masyarakat baik itu usia muda maupun usia tua, selain ada dampak positive terdapat juga dampak negative dari penggunaan Internet. Dampak positive dari penggunaan Internet sangat banyak tetapi dampak negative dari penggunaan Internet juga banyak seperti yang disampaikan diatas. Angka penggunaan Internet di Indonesia sudah sangat banyak, Kominfo mencatat bahawa ada sekitar 80 juta pengguna Internet di Indonesia dan itu menempatkan Indonesia pada peringkat ke 8 dunia dalam penggunaan Internet, dari jumlah pengguna Internet tersebut, 80 persen di antaranya adalah remaja berusia 15-19 tahun. Untuk pengguna Facebook, Indonesia diperingkat ke-4 besar dunia, tidak dapat dipungkiri bahwa dibalik manfaatnya Internet juga menimbulkan banyak mudarat dan dampak yang mengkhawatirkan, mulai dari pornografi, kasus penipuan, dan kekerasan yang semua bermula dari dunia maya (Kemkominfo, 2013). 
Tabel 1. Perbandingan Aplikasi yang di Buat Dengan Aplikasi Lain

\begin{tabular}{|c|c|c|c|}
\hline No & Aplikasi & Fitur / Kelebihan & Kekurangan \\
\hline 1 & $\begin{array}{l}\text { Menggunakan } \\
\text { Notepad }\end{array}$ & Memblok alamat ip. & $\begin{array}{l}\text {-Hanya dapat memblok } \\
\text { alamat } i p . \\
\text {-Hanya dapat digunakan di } \\
\text { komputer client. } \\
\text {-Hanya beroperasi pada } \\
\text { sistem operasi windows. } \\
\text {-Sulit dioperasikan. }\end{array}$ \\
\hline 2 & Blue Life Host Editor & $\begin{array}{l}\text {-Mudah digunakan. } \\
\text {-Dapat memblok alamat website. } \\
\text {-Tampilan menarik. }\end{array}$ & $\begin{array}{l}\text {-Hanya dapat digunakan } \\
\text { pada komputer client. } \\
\text {-Hanya dapat memblok } \\
\text { melalui alamat } i p .\end{array}$ \\
\hline 3 & $\begin{array}{l}\text { NoVirusThanks } \\
\text { Website Blocker }\end{array}$ & $\begin{array}{l}\text {-Tampilan yang simple. } \\
\text {-Memanipulasi file host windows. } \\
\text {-Dapat menggunakan alamat } \\
\text { website dalam memblok. }\end{array}$ & $\begin{array}{l}\text {-Hanya dapat di gunakan di } \\
\text { komputer client. } \\
\text {-Hanya dapat di gunakan } \\
\text { pada komputer windows. }\end{array}$ \\
\hline 4 & Host Mechanic & $\begin{array}{l}\text {-Tampilan lebih mudah } \\
\text { dibandingkan No Virus Thanks } \\
\text { Website Blocker. } \\
\text {-Dapat memblok menggunakan } \\
\text { alamat ip. } \\
\text {-Dapat memblok menggunakan } \\
\text { alamat situs. }\end{array}$ & $\begin{array}{l}\text {-Hanya dapat dipakai di } \\
\text { komputer client. } \\
\text {-Hanya dapat digunakan } \\
\text { pada komputer windows. } \\
\text {-User harus melakukan } \\
\text { berbagai macam } \\
\text { konfigurasi terlebih dahulu. }\end{array}$ \\
\hline 5 & Any Web Block & $\begin{array}{l}\text {-Dapat memblok menggunakan } \\
\text { alamat ip - Dapat memblok } \\
\text { menggunakan alamat } u r l . \\
\text {-Tidak perlu merubah alamat ip } \\
\text { yang ingin di blok. }\end{array}$ & $\begin{array}{c}\text {-Hanya dapat digunakan } \\
\text { pada komputer client. } \\
\text {-Hanya dapat digunakan } \\
\text { pada windows. } \\
\text {-User harus melakukan } \\
\text { export import apabila ingin } \\
\text { menggunakan aplikasi ini. }\end{array}$ \\
\hline 6 & Web Blocker & $\begin{array}{l}\text {-Dapat memblok alamat } u r l \\
\text { ataupun alamat ip. } \\
\text {-Mempunyai tamplate yang } \\
\text { menarik. } \\
\text {-Dapat memisahkan beberapa } \\
\text { kategori dalam memblok. }\end{array}$ & $\begin{array}{l}\text {-Hanya dapat di akses oleh } \\
\text { kopmputer windows. } \\
\text {-Hanya dapat memblok } \\
\text { alamat website dan ip. }\end{array}$ \\
\hline 7 & Aplikasi monitoring & $\begin{array}{c}\text {-Dapat memblok alamat website. } \\
\text {-Dapat memblok keyword yang di } \\
\text { gunakan pada google. } \\
\text {-Dapat di akses oleh komputer } \\
\text { server. } \\
\text {-Dapat diakses di segala sistem } \\
\text { operasi. } \\
\text {-Dapat diakses menggunakan } \\
\text { komputer client. } \\
\text {-Dapat diakses melalui gadget } \\
\text {-Sangat mudah dalam } \\
\text { pengoperasiannya. }\end{array}$ & \\
\hline
\end{tabular}




\subsection{Langkah Menerapkan Internet Sehat}

Demi mencapai Internet sehat selain dari diri sendiri untuk dapat mengkontrol dan menahan diri untuk tidak melakukan hal hal negative dari penggunaan Internet ada beberapa langkah agar kita dapat menerapkan Internet sehat dengan langkah :

1. Tidak melakukan pelanggaran hak cipta content seperti mencuri content orang lain, menjiplak, mendistribusikan ulang tanpa izin dari si pemilik.

2. Tidak menyebarkan malware atau tindakan hacking dan tidak memprovokasi satu dengan lain.

3. Melakukan blokir terhadap situs illegal dan pishing seperti situs dewasa, judi, trafficking dengan langkah membuat DNS tersendiri.

4. Memilih ISP atau penyedia Internet yang telah memblokir daftar situs illegal. Langkah ini tentu sangat membantu agar tidak semua orang dengan bebas mengakses content yang di larang.

5. Berikutnya campur tangan pemerintah di butuhkan dalam membuat undangundang dalam dunia ITE lebih ketat lagi.

6. Sebagai pengguna Internet kita harus belajar memahami bagaimana etika dan aturan yang seharusnya dalam aktivitas Internet.

\subsection{Aplikasi}

Demi mendukungnya program Internet sehat dan memberikan batasan-batasan dalam pengaksesan Internet maka disini diperkenalkan aplikasi berbasis web. Aplikasi yang digunakan untuk membatasi baik itu alamat website ataupun keyword yang digunakan dalam pengaksesan Internet. Aplikasi ini terhubung dengan Squid3 yang berada pada komputer server, aplikasi ini berbasiskan web, sehingga dapat mempermudah admin dalam membatasi pengaksesan Internet, perbandingan aplikasi ini dengan sistem yang lain adalah apabila admin ingin menambahkan atau menghilangkan alamat website yang diblok harus mengakses komputer server kemudian masuk ke Squid3 terlebih dahulu dan melakukan konfigurasi disana. Bagi admin yang tidak familiar dengan konfigurasi Squid3 maka akan merasa kesulitan apabila harus melakukan konfigurasi, dan juga dapat menyita waktu apabila harus melakukan pembatasan pengakseskan Internet dengan menggunakan sistem yang lama. Terlebih lagi aplikasi ini dapat diakses melalui komputer client ataupun menggunakan gadget dengan catatan terhubung dalam jaringan yang sama.

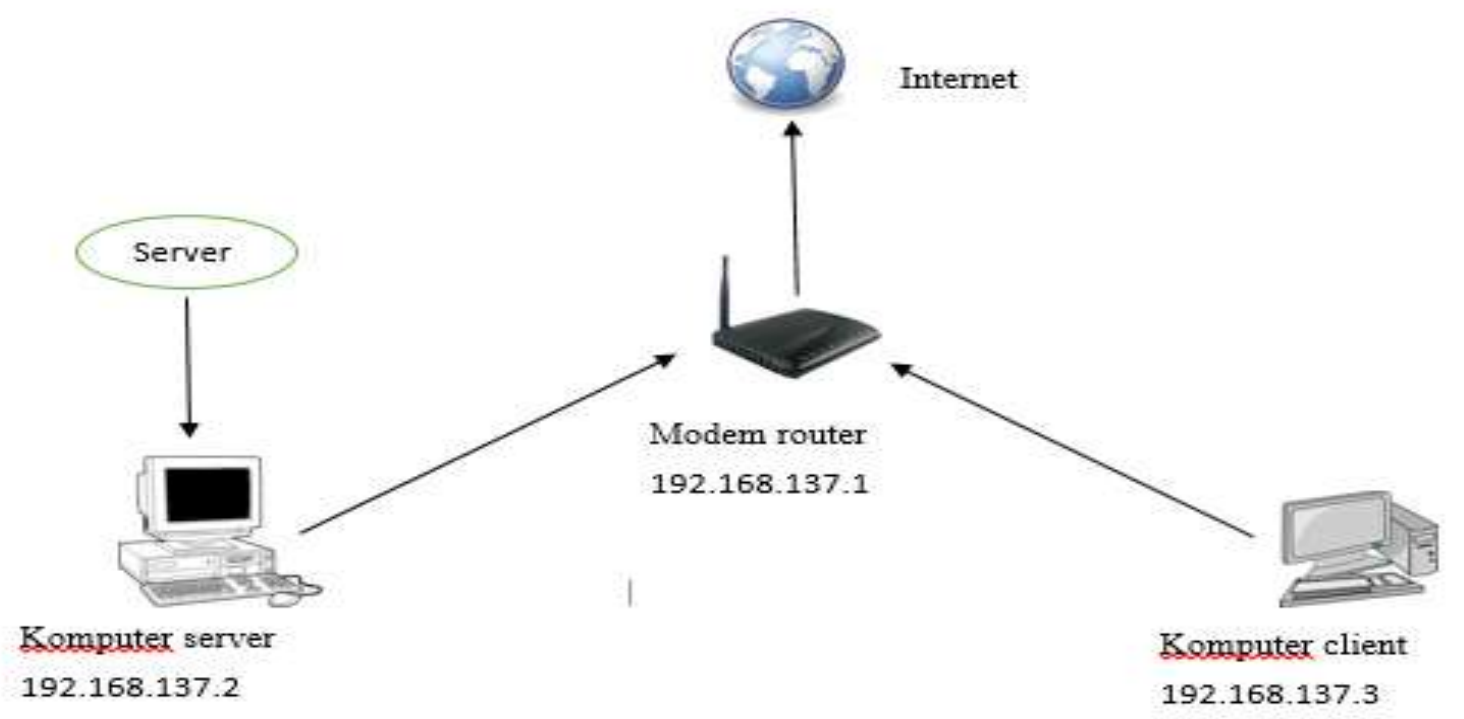

Gambar 1. Topologi Sistem. 


\section{METODE PENELITIAN}

\subsection{Gambaran Umum Sistem}

Dalam topologi tersebut terdapat satu buah komputer server, satu buah komputer client dan satu buah modem router yang masing - masing memiliki fungsi berbedabeda, komputer server memiliki alamat ip 192.168.137.2, komputer client memiliki alamat ip 192.168.137.3 sedangkan modem router memiliki alamat ip 192.168.137.1, aplikasi Squid3 dan admin terpasang di komputer server, karena komputer server adalah pusat dari segala pengaturan dalam topologi ini, komputer server menggunakan sistem operasi Linux Ubuntu server sementara untuk komputer client menggunakan sistem operasi Windows 8, dalam topologi ini menggunakan satu buah modem router yang bertujuan untuk menghubungkan antara komputer server dan komputer client dengan Internet.

Pengujian menggunakan satu buah komputer proxy server, satu buah modem, satu buah Router, satu client, untuk lebih rincinya pertama komputer proxy server mendapatkan akses Internet melalui modem router, kemudian komputer client terkoneksikan dengan router modem dengan terkoneksinya komputer client kepada router sehingga komputer client dapat mengakses Internet dengan konfigurasi Squid3 yang berada di komputer proxy server.

\subsection{Skenario Pengujian}

Untuk pengujian sistem ini pertamatama menyiapkan satu buah komputer server yang sudah terinstal proxy, satu buah router wifi, satu buah modem dan dua buah komputer client. Setelah semua perangkat telah siap digunakan maka langkah selanjutnya adalah dengan menjalankan konfigurasi proxy di komputer server kemudian menjalankan aplikasi, hubungkan komputer server dengan modem agar komputer server dan client dapat mengakses ke Internet. Setelah itu lakukan koneksi antara komputer server dengan wifi kemudian koneksikan komputer client dengan wifi tersebut. Dalam analisa ini di asumsikan bahwa antara komputer server dan komputer client menggunakan satu jaringan yang sama yang terhubung melalui wifi, apabila sistem berjalan dengan benar maka konfigurasi daftar website dan kata yang diblok tidak akan dapat di akses oleh komputer client, dan juga apabila sistem berjalan dengan benar maka aplikasi dapat di akses melalui komputer client baik itu melalui laptop ataupun melalui gadget. Dalam mengakses aplikasi tentu saja di perlukan login terlebih dahulu yang hanya dapat di akses oleh admin tersebut.

\subsection{Perancangan}

Use case diagram merupakan pemodelan untuk menggambarkan sistem secara keseluruhan. Diagram ini mendeskripsikan interaksi antara satu atau lebih admin dengan sistem yang di buat. Pada use case diagram ini hanya terdapat 1 aktor yang terlibat di dalamnya, yaitu admin.

Admin dapat mengelola sistem admin seperti menghapus dan menambah daftar website yang diblokir, menghapus dan menambah kata yang diblokir, menghapus dan menambah akun admin. Untuk memahami lebih lanjut use case diagram sistem admin dapat dilihat pada gambar 2 .

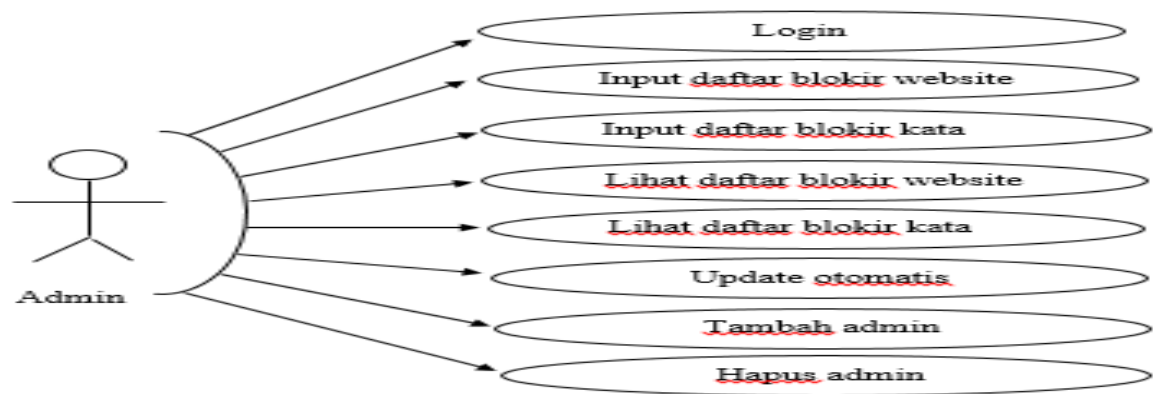

Gambar 2. Use Case Diagram Admin. 
Pada gambar 3 dapat dijelaskan bahwa proses untuk menginput daftar website yang akan diblokir oleh seorang admin. Pertamatama seorang admin akan login untuk dapat masuk kedalam sistem kemudian apabila berhasil akan masuk kedalam tampilan awal dari admin. Selanjutnya proses akan di lanjutkan kedalam menginput daftar website kemudian daftar tersebut akan tersimpan pada Squid3 yang terdapat pada server. Setelah berhasil admin dapat menguji daftar website yang diblokir tersebut apabila berhasil maka semua berjalan dengan baik dan website pun akan terblokir.
Pada gambar 4 dapat dijelaskan bahwa proses untuk menginput daftar kata yang akan diblokir oleh seorang admin. Pertamatama seorang admin akan login untuk dapat masuk kedalam sistem kemudian apabila berhasil akan masuk kedalam tampilan awal aplikasi. Selanjutnya proses akan di lanjutkan kedalam meng-input daftar kata kemudian daftar tersebut akan tersimpan pada Squid3 yang terdapat pada server. Setelah berhasil admin dapat menguji daftar kata yang diblokir tersebut apabila berhasil maka semua berjalan dengan baik dan katapun akan terblokir.

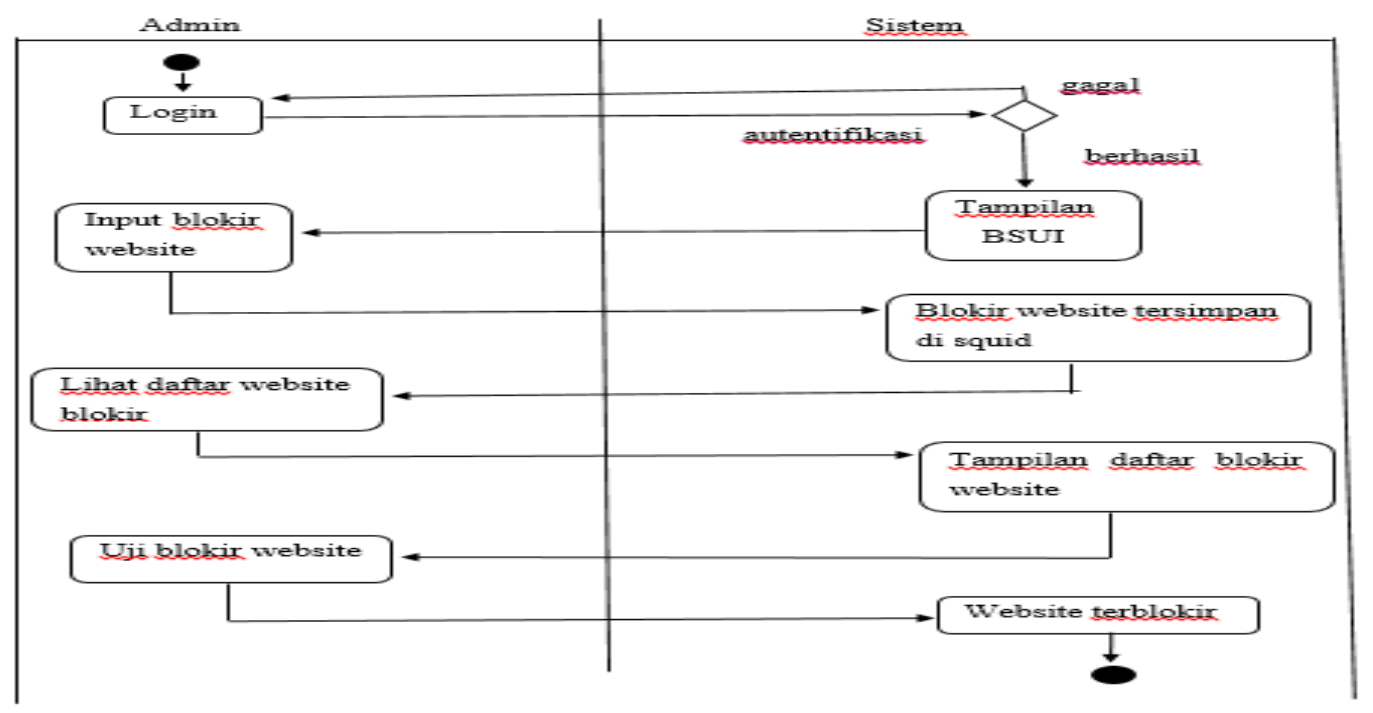

Gambar 3. Activity Diagram Blokir Website.

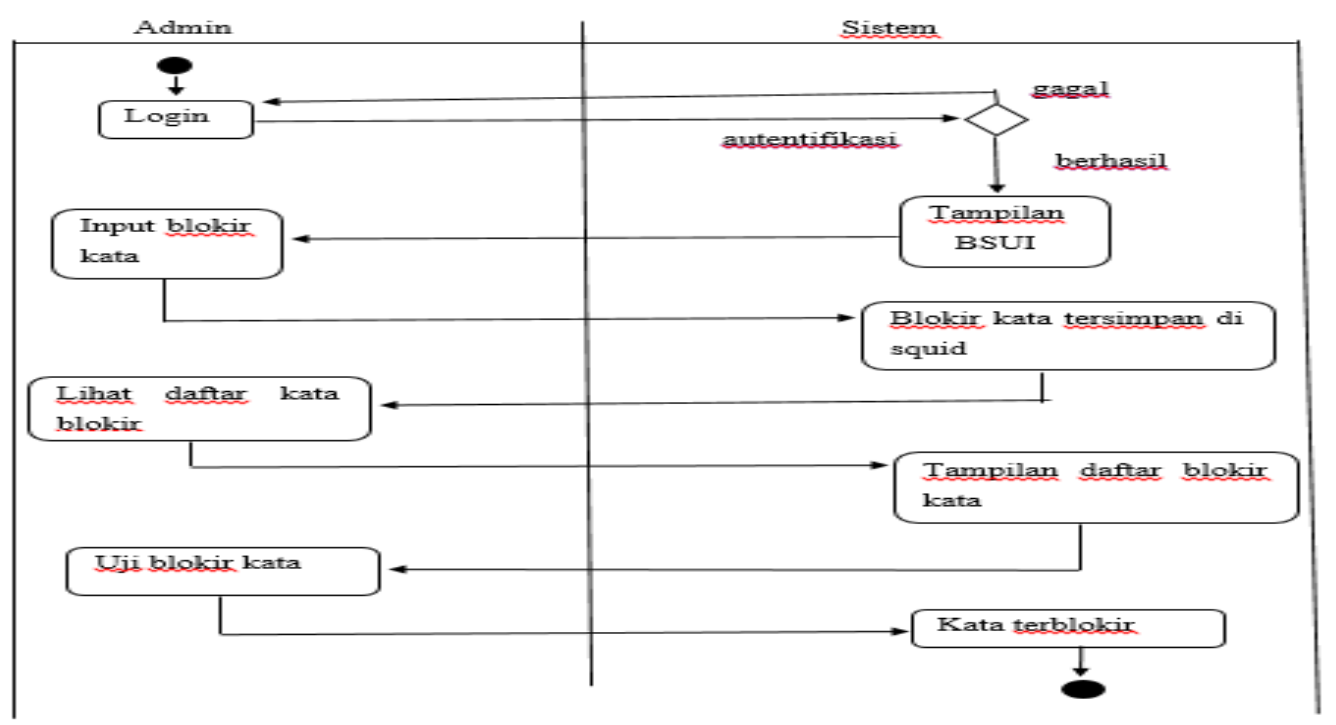

Gambar 4. Activity Diagram Blokir Kata. 
Pada gambar 5 halaman awal aplikasi terdapat kolom untuk menambahkan daftar website dan kata - kata yang akan diblokir. Selain dapat menambahkan daftar - daftar yang akan diblokir pada halaman ini juga admin dapat melihat website dan kata - kata apa saja yang sudah diblokir sebelumnya. Ada tombol update yang berfungsi untuk melakukan update database yang semuanya terhubung dengan Squid3 yang terdapat pada komputer server.

\section{HASIL DAN PEMBAHASAN}

\subsection{Hasil Input Daftar Blokir Website dan} Kata

Untuk dapat menjalankan sistem aplikasi dari aplikasi maka di perlukan database yang berisi alamat - alamat website dan kata - kata yang ingin diblokir oleh admin. Untuk dapat menambah daftar website dan kata yang ingin diblokir dapat dilakukan dengan langkah melakukan input melaui server dan input langsung dari aplikasi.

\subsection{Hasil Alamat Website di Blokir}

Dari gambar 7 dapat dilihat bahwa aplikasi sudah berjalan dengan baik di dalam komputer client, website porno.com telah berhasil diblokir dan tidak dapat di akses oleh client yang terhubung dengan jaringan yang sama pada komputer server.

\subsection{Hasil Keyword di Blokir}

Dari gambar 8 dapat dilihat bahwa aplikasi dapat memblokir kata-kata yang diinginkan oleh admin yang terdapat pada database aplikasi, apabila komputer client yang terhubung dengan komputer server dengan satu jaringan yang sama maka dapat di pastikan bahwa kata - kata tersebut tidak dapat di akses oleh komputer client.

\subsection{Hasil Update Ototmatis}

Sistem aplikasi memiliki fitur untuk melakukan update data secara otomatis yang akan terhubung dengan website yang dimiliki oleh Kominfo. Setelah selesai mendownload data - data tersebut akan di simpan dalam folder blokir_auto.txt yang terdapat pada server.

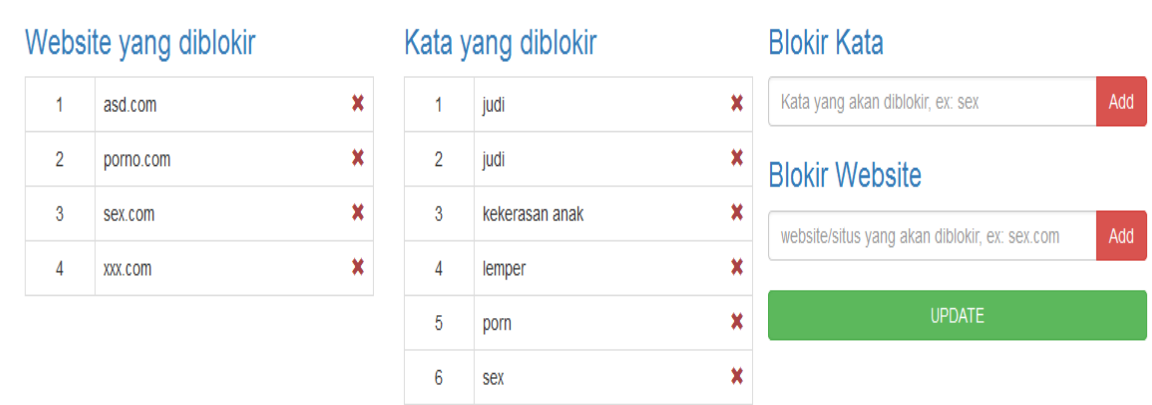

Gambar 6. Input Daftar Blokir.

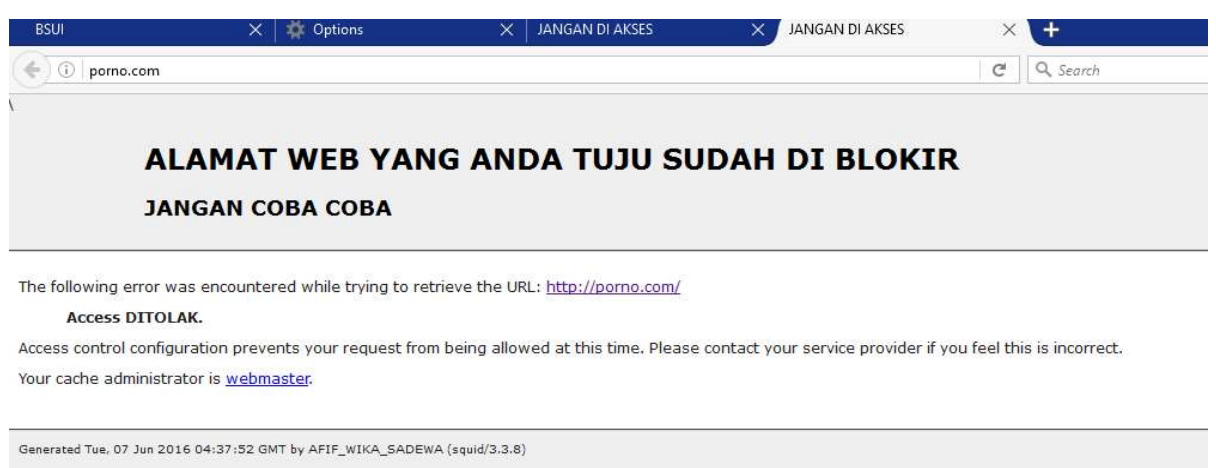

Gambar 7. Hasil Blokir Website. 


\section{HASIL DAN PEMBAHASAN}

Dalam melakukan uji coba sistem yang perlu dilakukan adalah menginput daftardaftar website dan kata - kata yang ingin di blokir. Daftar - daftar tersebut adalah hal hal yang mengandung kejahatan dan pornografi, untuk memasukan daftar yang ingin diblokir admin hanya perlu mengakses aplikasi melalui browser yang telah tersedia kemudian input nama website dan kata yang ingin diblokir, dengan begitu secara otomatis daftar tersebut sudah masuk kedalam folder yang terdapat pada Squid3 Proxy.

Kemudian setelah itu komputer client akan mencoba mengakses beberapa nama website dan kata - kata yang diblokir apakah sistem telah berhasil berjalan dengan baik atau terdapat suatu kendala. Selain dapat menguji daftar website dan kata - kata yang diblokir komputer client juga dapat mengakses aplikasi melalui gadget ataupun laptop apabila semuanya terhubung dengan satu jaringan yang sama, tetapi hanya admin saja yang dapat mengakses karena saat mengakses aplikasi tersebut dibutuhkan login dan hanya admin saja yang memiliki akun diaplikasi.

Setelah mendapatkan hasil dari sistem aplikasi maka dapat didapatkan langkah untuk mencegah penyalahgunaan media Internet dalam kehidupan sehari - hari, dengan begitu dapat mengurangi dampak yang ditimbulkan dari penyalahgunaan Internet sehingga dapat membantu program pemerintah Internet sehat di kalangan masyarakat pada umumnya dan kalangan rumah tinggal pada khususnya.

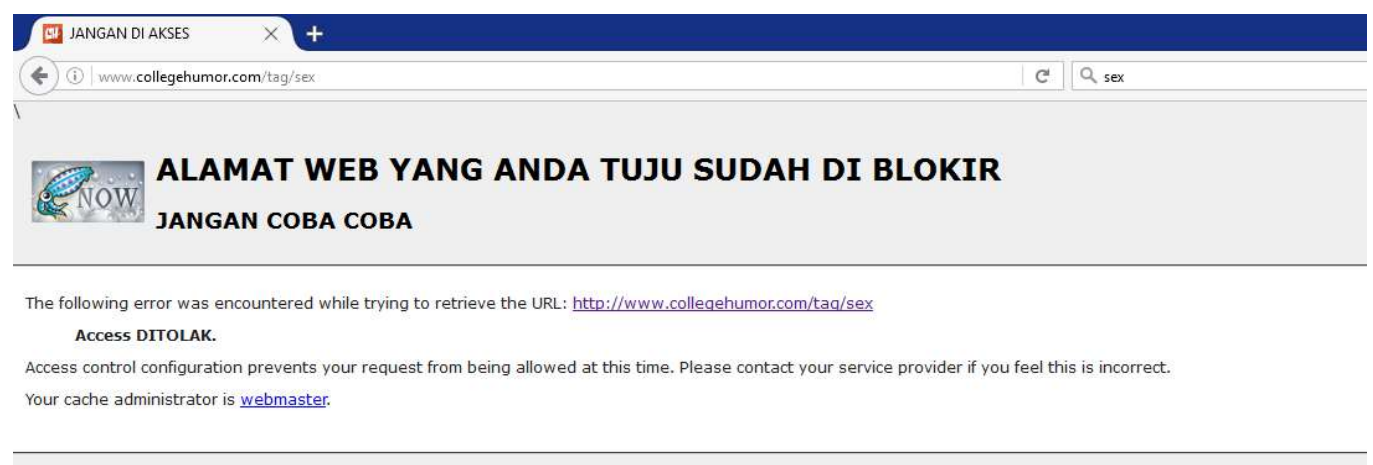

Gambar 8. Hasil Blokir Keyword.

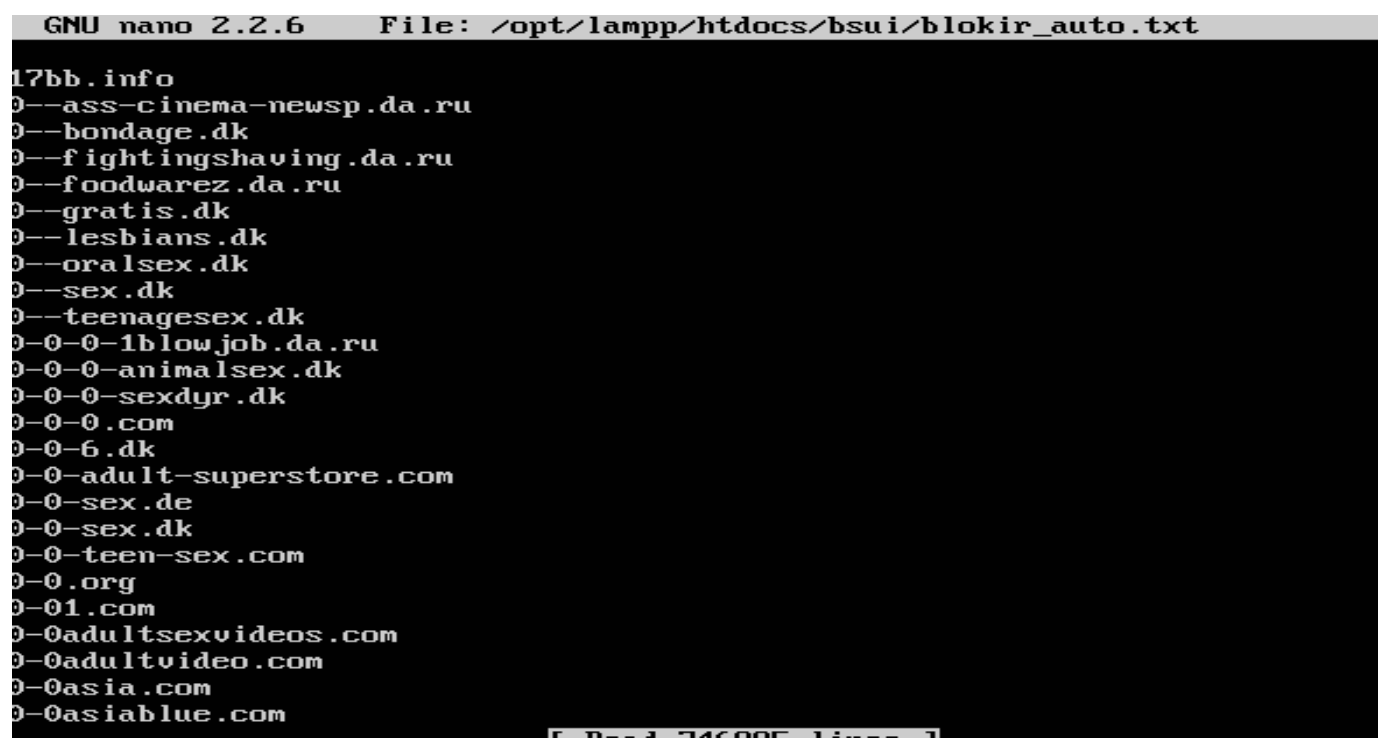

Gambar 9. Hasil Update Otomatis. 


\section{KESIMPULAN DAN SARAN \\ 6.1. Kesimpulan}

Sistem aplikasi memiliki fungsi unutk memblok atau membatasi pengaksesan di media Internet oleh pengguna. Dengan adanya sistem ini maka di harapkan dampak penyalahgunaan dalam media Internet dapat di turunkan sehingga dapat membatasi segala aktivitas pengguna di Internet.

\subsection{Saran}

Setelah selesai melakukan perancangan, pembangunan, implementasi dan mendapatkan hasil dari sistem yang telah di buat maka ada beberapa saran yang perlu di kembangan untuk memperkuat performa dari aplikasi, berikut adalah beberapa saran yang diperlukan untuk memperkuat performa dari aplikasi yaitu :

1. Aplikasi dapat di kembangkan dari segi performanya agar komputer client dapat dengan otomatis menggunakan konfigurasi dari aplikasi.

2. Selain untuk membatasi aktivitas client di Internet aplikasi juga dapat di kembangan ketahap dapat digunakan untuk memantau aktivitas client di Internet.

3. Aplikasi BSUI dapat memblokir https.

\section{DAFTAR PUSTAKA}

Dulkifli., 2015. winscp. Retrievedfrom http : // pecandukreativitas . blogspot . co.id / 2015 / 05 / pengertianwinscp.html.

Fauzi, R., 2014. SEJARAH LINUX . Retrievedfrom http : // reynaldifauzi99 .blogspot .co .id / 2014 / 01 / sejarah-dan-pengertianubuntu.html.

Kemkominfo., 2013. internetsehat. Retrievedfrom https : // kominfo .go . id / index.php / content / detail / 3303 / Internet-Sehat-dan-Aman-INSAN-/0/internet_sehat.

Mariadi, A., 2015. Pengertian Sublime Text Editor. Retrievedfrom http : // www.pemulabelajar.com / 2016 / 03 / pengertian-sublime-texteditor.html.

Setyawati. N., 2011.

Pengertian_Aplikasi_Putty.co.id.Re trivedfrom https : // Pengertian_Putty.net / 2011 / 12 /pengertian_aplikasi_putty.html.

Opray., 2014. Fungsi xampp. Retrieved from http : // opraywinter.blogspot.co.id / 2014 / 11 / definisi-pengertian-danfungsi-xampp.html. 
Sarry, I. W., 2013. Squid merupakan salah satu contoh aplikasi dari Proxy. Retrieved from http : // inawulansary.blogspot.co.id/ 2013 / 02 / pengertian-tentang-squid-danproxy.html.

Sutisna, A., 2015. Pengertian Dan Fungsi Virtualbox. Retrieved from http : // keranjangnetwork.blogspot.co.id / 2015 / 02 / pengertian-dan-fungsivirtualbox.html.

Agustina. T., 2013.

Pengertian Internet Sehat. Retrived from https : / / pengertianinternetsehat.co.id / 2015 $/ 02$ / pengertian_internet_sehat.

Rini. D., 2013. Definisi Windows 8. Retrived from http : // Sejarah_Windwos.co.id/2013/10/ Definisi_Windows8.html.

Rachman. A., 2013. Definisi_Proxy_Server. Retrived from https : // definisiproxyseerver.net / 2013 / definisi_internet_sehat. 